\title{
Intimate strangers: perspectives on female converts to Islam in Britain
}

\author{
Dorothea A. Ramahi $^{1}$ - Yasir Suleiman ${ }^{1}$
}

Published online: 5 January 2017

C) The Author(s) 2017. This article is published with open access at Springerlink.com

\begin{abstract}
This article explores the relationships between female converts to Islam in Britain and their close friends and family. It pays attention to the perspectives of converts but focuses on the reactions of their intimates to the conversion. We argue that converts become 'intimate strangers' through conversion-estranged on the level of understanding and belief but intimate on the emotional plane. This strangeness is symbolised by the Orientalist stereotypes associated with the converts. At the same time, friends and family shun engagement with the conversion itself, thus keeping alive the stereotypes and precluding understanding. In refusing to engage with matters of belief even within the intimate space of the family, secularism's orthodox private/public divide gets busted where religiosity, instead, becomes an issue between the (individual) private and the (family) public. Lacking reciprocity and with no access to the inner depths of the people they are closest to, the liberal rhetoric of friends and family about personal choice and equal acceptance of all paths amounts to bigotry and turns out to be painful for both the converts and their intimates.
\end{abstract}

Keywords Islam · Conversion · Britain · Orientalism $\cdot$ Family $\cdot$ Secularism

\section{Becoming intimate strangers}

What appeared as most striking during the interviews with converts and their intimates ${ }^{1}$ was the 'benign neglect' encountered on the part of friends and family. While we encountered hostile remarks on the conversions from intimates as well as considerably fewer positive comments, the perceptions overall were characterised by a lack of

\footnotetext{
${ }^{1}$ We use the term 'intimates' throughout this article in referring to friends and family of the converts.
}

Dorothea A. Ramahi

dab66@cam.ac.uk

1 Faculty of Asian and Middle Eastern Studies, HRH Prince Alwaleed Bin Talal Centre of Islamic Studies University of Cambridge, Sidgwick Avenue, CB3 9DA Cambridge, UK 
interest. Two questions we asked our respondents were: "Have you in any way tried to engage with [the convert] in order to understand her reasons for converting?" and "Have you tried to learn about Islam?". What we did not expect was that most people would answer these questions with a straightforward "No". A few people explained how they had tried to engage and only Noura's friend Dave responded with some sense of conviction: "Of course I have! What kind of friend would I be if I hadn't done that?". Reading this response may find many people in natural agreement but in fact few family members thought engagement was called for. What prevailed was a sense of rejection with the statement "I'm not interested" being uttered numerous times throughout the interviews.

This article explores the relationships between female converts to Islam in Britain and their friends and families. It is based on a mixed method of interviews combined with participant observation. After an initial contact with three women, the rest of the participants were recruited through snowballing. We conducted semi-structured interviews with nine converts and seven of their friends and family members, including fathers, mothers and sisters. Sometimes converts spoke about their relatives and how they had reacted but we did not have the chance to speak to them. In these cases the findings are taken as presented by the converts. The fieldwork also included spending time at the homes of converts and their relatives where some of the interaction between them could be observed and participating in a local Dhikr-circle ${ }^{2}$ where converts talked about their experiences with friends and family. Our fieldwork took place in 2013 in different places across South England and included people from very diverse religious and ethnic backgrounds. All of the women had converted to Sunni Islam and two belonged to a Sufi order.

On the one hand, we use the converts' accounts of their conversion and how these affected their intimate relationships. On the other hand, we incorporate the perception of friends and family, how they experienced the conversion and how it changed the way they relate to the convert. We surmise that through conversion, these women move into a position of alterity with respect to their closest social network, thus becoming 'intimate strangers'. ${ }^{3}$ Our conjecture is based on the understanding that religious conversion entails drastic change with respect to both the self and others (Snow and Machalek 1984). It also draws on the prevalent Orientalist notions of Islam as Europe's ultimate 'Other' (Said 1978), which have recently been revived in the social sciences by Huntington's (1993:39) fervent declaration that the 'bloody fault lines of Islam' would become the unbridgeable chasm in the "clash of civilisations" between "the West and the rest". We infer that the resulting "block thinking" (Taylor 2007) has had such profound impact on people's ways of conceptualising the world that even in the most intimate contexts it will become visible.

Although anthropology is concerned with the 'Other', anthropologists have - to our knowledge - not investigated the relationships between converts (to Islam) and their close social networks. Most studies of conversion across the disciplines have been

\footnotetext{
${ }^{2}$ Dhikr, meaning "remembrance", is an Islamic ritual, which involves the recitation or chanting of the names of God, supplemented by verses from the Qur'an and hadith. It is a form of prayer.

${ }^{3}$ We borrow the notion of the 'intimate stranger' from the context of divorce. Matthew (1984:19) uses the term to describe the failure of couples to cater to one another's "innermost needs" thus resulting in divorce. The lack of understanding between people most intimately linked in a marriage turns them into "intimate strangers'.
} 
centred on the converts themselves. Topics of investigation have been the reasons for conversion (Köse and Loewenthal 2000; Köse 1999; Lakhdar et al. 2007; Lofland and Skonovd 1981; Rambo 1999), the meaning of conversion (Köse 1994; van Nieuwkerk 2008; Wohlrab-Sahr 1999; Woods 2012), conversion and modernisation (Köse 1999; van Nieuwkerk 2006; Woods 2012; Zebiri 2008), conversion and resistance (Comaroff and Comaroff 1991; Woods 2012), conversion and the hijab (Tarlo 2007), continuity and change in conversion (Chua 2012; Robbins 2007) and the negotiation of identity (Afshar 2008; Sartawi and Sammut 2012; Zebiri 2008). Many of these studies clearly recognise the social dimensions of conversion and the impact it has on the converts' immediate social environment. Woods (2012:449), for instance, explains that "conversion engages with, informs and ultimately disrupts existing notions of meaning and identity, and impacts individuals, families, communities and the religious groups that represent old and new affiliation" and argues that "a robust conversion discourse should consider, but also transcend, the changing religion or beliefs of an individual" (ibid.:441). Zebiri (2008); Moosavi (2011) and Köse (1996) focus on converts to Islam in Britain. They recognise the social dimension of conversion and the relationships with friends and family enter their accounts through the eyes of the converts. However, since relationships are inherently dialogical the picture their studies yield is partial in this respect. During our investigations we explicitly tried to construct the impact of conversion on intimate relationships through the perspectives of both converts and their relations.

\section{Orientalism alive}

As has been vividly illustrated by numerous scholars since the publication of Said's (1978) Orientalism, the received construction of Islam as Europe's 'Other' harks back centuries and is still present in modern media discourse and elsewhere (Asad 1993, 2003; Gilliat-Ray 2010; Zebiri 2008, 2011). In the Orientalist perspective Islam is constructed as a static, monolithic and backward doctrine that both explains and determines Muslims' behaviour. It is inherently reductionist in viewing Muslims almost exclusively through the prism of religion and rests on a dyadic construction, in which the 'Orient' is seen as essentially and, hence, irreconcilably different from and inferior to the 'Occident' (Afshar 2008:412-3; Bullock 2002:xviii; Said 1978:49). ${ }^{4}$ The positioning of Islam as the 'Other' of a Judeo-Christian Europe emerged in Rachel's (59) comment on her sister's conversion: "If she had converted to a religion that wasn't so counter-opposed to Judaism... if she had converted to be a Buddhist that's not so counter-opposed to Judaism, that's not in conflict with Judaism." When the interviewer pointed out that Judaism had much more in common with Islam than with Buddhism, she agreed but said that such had been her perception at the time of conversion 33 years ago.

Even though the discourse about the Muslim world has markedly changed over time, the themes remained essentially the same throughout. The themes that most frequently emerge as a marker of difference are the status of Muslim women as sensual but oppressed and religiously motivated violence both on state and individual levels

\footnotetext{
${ }^{4}$ While Said's work primarily focuses on Western Orientalist scholarship it also encompasses popular culture as well as images created in literature and the media (Said 1997).
} 
(Afshar 2008:414; Bullock 2002:xxxiii; Esposito 2011:xxxii; Zebiri 2011:185). Even though Orientalist perspectives are by definition directed towards the Muslim/Arab/ Oriental 'Other' who is usually thought to be outside of Europe (Asad 2003:171) either spatially or conceptually (e.g. immigrants), some of this received stereotypical thinking also became directed towards the converts. Often coming from a white British or European background, converts were being 'Orientalised' by their friends and family to varying degrees. This is mirrored by an earlier study in which convert women reported being called 'White Pakis' (Suleiman 2013: 37). We perceive this 'Orientalisation' to be an important component in making converts into 'intimate strangers'.

\section{Women \& the hijab: measuring distance}

Respondents were usually careful to distinguish between Muslim women in general and the converts. However, even where some people initially denied any potential associations of Islam with women's oppression, they did come through in several interviews and were ultimately also applied to the converts themselves. The fathers that were interviewed - and other converts reported the same about their fathersperceived women in Islam as "second class citizens". While some friends and family emphasised they knew well that their friend or sister was enjoying an equitable relationship with her husband and acted out of her own will, the fathers interviewed held on to the view that their daughters had converted to Islam because of their husbands (see also Brice 2010:18). As Sana's father (aged 80) put it: "If she hadn't married him she wouldn't have become a Muslim... there is no reason she should be a Muslim otherwise". Inherent in this perception is a notion of the woman's dependency on the man and the idea that her actions are not really of her own choosing but that she acted because of and ultimately for her husband. The reverse idea, that a woman's inclination to Islam may in fact have led her to marry a Muslim man, was absent from their discourse. The comment links up with Moosavi's (2011:263-4) elaboration on the "Islamophobic prejudice", which plays out in the form of dismissing the conversion or attributing it to "other reasons". In Moosavi's as well as our findings, the idea that the converts had turned to Islam for their husbands was particularly obstinate and resistant to correction even though the converts had repeatedly tried to explain that even without their husbands they would still be Muslim and that -if they were ever to get divorced - they would still keep the faith. As one participant in Suleiman's (2013: 39) study put it: 'ditch the man but keep the Islam'. The bottom-line of such 'explanations' is that Islam in itself does not seem to offer anything of value so that other reasons for conversion have to be found.

The hijab as an emergent theme in our interviews is intimately linked with the status of women in Islam as part of the Orientalist picture. Many women spoke highly of the hijab, calling it a "mirror of identity" or said that they felt "very comfortable" and "at home" in it. Some emphasised how the hijab had served as a signal to other Muslims and how they had gotten to know new people by wearing it (see also Tarlo 2007:151). All of the women who wore or had worn the hijab attached great importance to it and almost unanimously reported that it served as a form of "protection from unwanted looks", "a shield against chauvinism", a "nice filter" or a protection against "smut". As a seeming paradox, several women had encountered disadvantage, harassment or even 
violent assault (losing their job, being spat at, being insulted, having a stone thrown at them and being stared at) because they wore the hijab and yet, they all agreed that it protected them (Tarlo 2007:143; van Nieuwkerk 2008:443). Primarily, it became clear, it protected them against the "male gaze", which apparently and counter-intuitively was perceived as a greater threat than verbal or physical abuse attracted through the hijab.

Even though most converts saw the hijab primarily as a religious requirement, they all acknowledged the positive effect it had on their evading the male gaze. Many spoke of the increased respect with which they were now being treated - especially by menwith seats being offered in the tube, excuses being extended for bad language in their presence and a general upgrade in perception (see also Tarlo 2007:142). They all resented the objectification of women in British society, the sexualisation of the female body in advertisements and on billboards and the impact these had on how women were seen and treated. Jane (31) reflected:

"I was looking around me thinking: women are becoming more and more objectified... to sell a car you're spreading a naked woman across it... I'm not gonna be part of that... I'm wearing a headscarf and I'm making a statement about, you know, judge me by my brains, not my looks, so I was almost cutting off chauvinism [...] if you are going to objectify my body then I'm just gonna completely hide it from you... So, it was actually a feminist statement".

Jane's sentiments mirror both Tarlo's and Werbner's discussion of the hijab. To Werbner (2012:116) it functions like "a protective shield against the male gaze" in preventing unwanted advances while Tarlo (2007:143) describes it as allowing women to be seen as "a human being rather than as a sexual commodity". The hijab, converts explained, helped them to be perceived "as a person", rather than a female body, and judged based on their inner values, rather than their "looks". As such the hijab represented a means of empowerment for many of the women (see also Asad 2003:79; Brenner 1996:674; Lee 2010:153; van Nieuwkerk 2008:434; Zebiri 2008:208).

Concerning the hijab, there was an enormous disconnect between the converts' perceptions and how friends and family looked at it. To many relatives the hijab was a nuisance. It seems warranted that Zebiri (2011:181) calls the hijab "the most powerful symbol of Muslims' otherness", signalling women's subjugation. In Zebiri's study many converts reported that their families had accepted their conversion until they put on the hijab, which caused hesitation for many converts in the decision to start wearing it (van Nieuwkerk 2008:444). It is in this vein that Scott (2007:124) suggests the "veil" represents a "conspicuous display of religious affiliation", which seems to be unwelcome in the modern secular society. While some people had voiced their neutrality towards the scarf, only Maryam's older sister Judith (63) had actually commented positively on the way it looked but most people disliked it. Whereas some chose to call it outright "silly" or "ridiculous", others said it was "a pity" and even "unnatural". Köse (1996:138) also refers to one convert telling him her father thought she had "taken a step back to the Middle Ages" when she started wearing the hijab, thus making explicit the linking of the hijab with backwardness (Afshar 2008:419).

The reasons for dismissing the hijab varied slightly. While some stressed that it could cause trouble in form of harassment for the convert, others made clear that the 
visibility of religion was bothersome to them. Sana's father explained: "It's up to her but it's a pity because it means in this country she stands out as being... erm a Muslim... which is a minority. A lot of people feel animosity towards Muslims". However, at other points and unrelated to the hostility that the hijab would expose Sana to, her father emotively exclaimed: "I think it's a pity that she [wears] it and I can't see any point in doing it either... I don't like it". "More and more", he said, he came to think that Islam was a "ridiculous religion".

Both Christine's and Noura's fathers expressed similar judgements ("silly", "ridiculous") but apparently for slightly different reasons. While Christine's father (61) expressed his concern about his daughter's becoming a victim of Islamophobia, and disliking the scarf in itself, he also explained: "I didn't want her to settle down or get involved with somebody before she went to [university]... I wanted her to be single so she could meet lots of different people... I was disappointed... she wouldn't go anywhere socially for drinking now". In this statement the father expresses his resentment about his daughter converting to Islam, getting married at the same time and adopting a 'settled' lifestyle, which would no longer allow her to go out in the same way that most undergraduate students would, experimenting with drinks and dates. Hidden beneath this sense of 'loss' seems to lie the perception that his daughter would not be able to fully live out her freedom while adhering to Islam. Ironically, it is the visibility of the hijab that the women embrace as a means for their own invisibility. Their outer appearance, their female body, becomes invisible to the male gaze, which in turn induces a boost in respect and a focus on the women's personality. At the same time it is precisely the visibility of the hijab that turns out to be so bothersome to the male family members in particular. Tarlo (2007:132) succinctly discusses the doublesignificance of the hijab as concealing the female body on the one hand and signalling visibility "as Muslim" on the other, often attracting 'kindred spirits' and evoking respect. It is striking that the converts' narratives converged with more consistency on this topic than on any other, which testifies to the iconicity of the hijab. As the hijab has become iconic of 'Muslimness' and Islam as a backward faith that oppresses women, converts tried to counter that iconic symbolism through their narratives.

\section{Violent stereotyping}

Like the status of women, violence has been an intrinsic feature of Orientalist scholarship from its inception. The notion of the "bloodthirsty" Muslim and the idea that Islam was "spread by the sword" were default assumptions beginning with the Crusades (Gilliat-Ray 2010:6). While at various points in history, such as the expansion of Al-Andalus or the spread of the Ottoman Empire, it was the encroaching Muslim armies that threatened various places in Europe, recent perceptions of violent Islam came in association with jihadist extremism and terrorism both inside and outside the 'West' (Zebiri 2011:175). Even though none of the respondents associated Muslim violence directly with the converts, the topic of terrorism and 'Islamic' violence curiously appeared in sometimes completely unrelated contexts and came to negatively influence perceptions. The association of Islam with violence as antithetical to a democratic Britain observant of human rights contributed to the converts' positioning as 'intimate strangers'. 
When Christine (20) was explaining the central tenets of Islam to her parents and elaborated that scholarly disagreements prevailed in Islamic law concerning many minor issues but that the central questions appertaining to the faith's content were agreed upon, her father suddenly interrupted asking: "Well, in that case then, what's the problem in Syria... where Muslims are killing Muslims?". This seemingly misplaced question highlights two things. One is the inherited Orientalist epistemology, according to which Muslims' actions are being deduced from and reduced to Islam; the fact that the Syrian conflict is first and foremost a political conflict is completely sidestepped in order to view it through Islamic spectacles. The other noteworthy facet of the question is that it apparently seems relevant and therefore warranted to bring up violent conflict while discussing Islamic theology. One wonders why the question would be deemed fit if it was not for the perception that violence is an inherent component of Islamic doctrine.

In a different context, Sana's father asserted that Muslims go on "suicide missions" by blowing themselves up. What is interesting about this perception of Islam-besides the same reductionist shortcomings of the previous example - is that his daughter had explained several times that such violence is neither prescribed nor in any way sanctioned by the Qur'an or Islamic doctrine. Sana's explanations only prompted him to say: "I can't believe it [her explanations]... it's got to be somewhere [in Islam], right?". While unwilling to actually read the Qur'an or try to find evidence for his assumptions, he chose to hold on to the received view and accept the image promoted in the media over the elaborations made by Muslims themselves. Reading the Qur'an is, of course, not in itself a remedy to either understand Islam or bridge the apparent intimacy issues. However, taking up the Qur'an and reading it signals a willingness to understand and a proactive step to engaging with the convert. What matters is not whether someone who takes up the Qur'an understands it or not, but the symbolic meaning of this action. Seeing their intimates reading the Qur'an symbolically signals to the converts a willingness to engage on part of their family members. In Orientalism Reconsidered Said (1985:97) re-emphasises the point already made in his foundational book that this refusal to accept Muslim self-representation is symptomatic of Orientalist thinking. It is the result of the superiority complex so deeply engrained in the Orientalist tradition that the Oriental subject about whom statements are being made has no credibility when confronted with the authoritative stance of the enlightened Western interlocutor. In the Orientalist tradition Muslims are seen as incapable of accurately representing themselves and therefore need to be represented by those who are more knowledgeable about Islam than they are. The outsider (here the media) is seen as being a better source of knowledge about Islam than the insider.

In the context of discussing both religiously motivated violence and the hijab, received images from the media seem to have led this father to a rejection of his daughter's conversion after he had initially accommodated it: "At first it didn't bother me, I think. Later on it did". He articulated his feeling "unhappy" with the religion and coming to think "more and more" that it was "a pity that she converted". In statements like these a clear change of heart becomes visible. Instead of going from an initial shock to slowly accommodating and accepting the conversion, Sana's father-and this is in line with what Malika reported of her father - started off with an attitude of indifference that later developed into outright rejection. Both women concerned are amongst the 'older' converts. Having converted in the late 70 s and early 80 s respectively they had 
received little to no reaction from their fathers at the time of conversion. Even though Malika's father, being an outspoken atheist, had voiced his disdain for "another nutcase in the family" (Malika's mother being a devout catholic), he had actually also voiced some relief at her settling down and finding her path in life.

At the time of conversion, Sana's parents said that they knew "of" Islam but that they "didn't know anything about it". It was a blank page. Malika articulated that she blamed the increasingly anti-Muslim media discourse, in particular post-9/11, for her father's hostile attitude. She mentioned that he watches a lot of TV and frequently confronts her with newspaper articles concerning terrorism and Islamic extremism. From not being "bothered" by their daughters' conversions these two fathers experienced a surge in hostility and rejection. It seemed that their change coincided with a shift in the national imaginary of Islam. Even though they did not directly associate their convert daughters with a violent image of Islam, the received Orientalist trajectory, which has been perpetuated with increased intensity after 9/11 in the media, did turn out to influence them in their perceptions of the conversion and caused them to reject it retrospectively. During the interviews it appeared both in direct conversation with parents and in what converts said about their parents that fathers seemed to struggle a lot more with accepting the conversion than mothers did. It is not possible to draw any conclusions as to why this is so based on the data collected. However, we put forward two conjectures, both of which would lend themselves to further research. On the one hand paternalistic structures or the remnants thereof might make a felt 'loss of control' over the daughter's path in life more painful for fathers. This resurfacing of the father as the 'head of the household' would question the notion that paternalistic family structures have been replaced with more egalitarian ones in a contemporary British context. On the other hand, it seemed that fathers relate to their daughters more via common interests and themes with which they can identify. As they no longer share the same opinions on many issues post-conversion fathers seemed to see less of a common ground with their child. Mothers appeared as less interested in discussing and arguing over news stories, technicalities and themes of common interest, and emphasised instead their unconditional love for and interest in the convert. Rather than perceiving the conversion as an affront against their worldview, mothers seemed to suffer more from the perceived lack or break of trust.

\section{Selective knowledge}

What became clear during the interviews was that many of the friends and family members had very selective knowledge about Islam and about Muslims, sometimes even after long periods of having a Muslim family member. Sana's father expressed his disapproval of the fact that "they are allowed to take more than one wife if they can afford it". Upon questioning whether he had ever tried to find out about such provisions or whether he had asked his daughter about it he said that he had, in fact, never enquired about any of it, that he was not interested and that - although his daughter had given him a copy of the Qur'an - he had never even looked at it. Christine's parents pointed to the fact that women in Saudi Arabia are not allowed to drive cars, said that there were "too many rules" in Islam, thought that other religions were much more "tolerant", felt mystified by the many "threats" [of hell] in the Qur'an and expressed the view that Islam was a "mean religion" for the apparent lack of gifts during birthday 
celebrations. Similar to the attitude presented by Sana's father, these parents did not really try to understand or seek an explanation for what they were criticising. Instead, they seemed to be building an 'argument-proof vest' in order to protect the prejudices at hand. When Christine pointed out that Judaism, too, entails a large set of rules, her father only commented: "Yes, but there are very few Jews who follow". Reminded that Christianity also entails "threats" regarding the menacing prospect of hell, he did not feel as threatened by these.

Concerning the Saudi prohibition on women driving it is worth pointing out that Saudi Arabia is, in fact, the only Muslim country in the world, which has such a law. Following inductive logic it seems strange that somebody would look at a statistical exception and make it into a general rule. This form of selective induction seems to hint at underlying assumptions about Islam, which make this exception into a relevant case. Even though statistically an exception, it somehow comes to reflect the true nature of Islam. Malika's report of her father's accusations concerning "Islamic terrorism" mirror a similar pattern. Whenever she tried to explain that the terror is neither prescribed nor sanctioned by Islam, her father would reply that she was not following the "real Islam" but instead, belonged to some fringe group, which had misunderstood its true meaning. Islam's "real" meaning in that case was being deduced from selective media reports about Muslim violence and the oppression of women. The disbelief regarding the converts' explanations ran through several of the interviews indicating that the convert's opinion was not taken seriously. Paradoxically, at times, some family members would expect the converts to explain violent events, thus treating them as representatives of Islam. This demand in and of itself is part of the monolithic Orientalist paradigm, reducing Muslims' actions to Islam (Zebiri 2011:184) and treating any Muslim as a representative of the entire religion (Tarlo 2007:146). Dissatisfied with the answer, they would subsequently go on to denounce the convert - the living and tangible example refuting their claims - as belonging to a fringe group, which failed to represent mainstream Islam, and hence was not to be taken seriously. This too, is emblematic of the Orientalist stance. As in Jauss' Reception Theory (Jauss 1982: 23), where a literary work (even if new) does not appear in an informational vacuum 'but predisposes its audience to a very specific kind of reception' it appeared that our interlocutors assimilated what was presented to them to their previously formed schemata. Information given by the converts was modified to match the pre-existing horizons of expectation.

Another explanation to these seemingly paradoxical expectations might be offered by Marianne Gullestad's concept of "negative hypervisibility". In Plausible Prejudice Gullestad (2006: 50-7) explores how Norwegian media outlets are consistently examining the oppression of immigrant women (mainly of Pakistani origin) through such themes as forced marriage, female circumcision, honour killings, and male violence towards their wives and children. In this discourse newspapers give a voice to specific "superprivileged" minority women who come of an immigrant background and publicly talk about their plight and their struggle against patriarchal traditions. While celebrating these highly visible, superprivileged voices, the media disregards the points of view of most minority people who are rendered voiceless in what Gullestad calls "negative hypervisibility". They are highly visible in the media's reports on their oppression and aggression yet muted, as they do not get the chance to explain their actions. In combining the positive visibility of a few superprivileged minority 'stars' 
with the negative hypervisibility and voicelessness of the minority's majority, the minority background itself becomes simultaneously very important and not important at all. In their struggle to represent themselves and Islam in a way that they would like to be seen, converts experience something reminiscent of Gullestad's "negative hypervisibility". While their minority status (Muslim) is the very reason Islam is made the subject of discussion with family members, this same minority status does not seem to give them authority to speak of Islam.

The selective knowledge brought up during the interviews is worth mentioning not because these prejudices are all untrue (though some of them certainly are) but because they are indicative of the associations that friends and family have when they think of Islam, and hence, of their tinted perceptions. The stereotypical thinking and ensuing 'folk' ideologies about Islam where cases like the Saudi legislation on women driving features prominently are naturalised in a way that make them hard to be questioned. The 'protective belt' that people build around their assumptions are indicative of the hegemonic status that these folk ideologies have, which moves them outside the "universe of discourse" and into Bourdieu's (1977:168-9) doxic "universe of the undisputed". As naturalisms, certain 'truths' are not up for discussion. In the postmodern sense of "ideology" we do not refer to political grand schemes or specific paradigms intended to contest or promote certain interests in society. Rather, ideology in this context refers to certain 'systems of meaning' (Geertz 1973:196). Like Foucault's (1976: 93-5) revolutionary conception of power as a subtle, omnipresent, systemic, and productive mechanism, rather than the authoritative and oppressive topdown binary envisioned hitherto, so ideology too is here meant as something "everyday", which is present not only in the political sphere but also in the private sphere of the family. In Bourdieu' discussion of ideology he conceptualises the world of ideas as split into two: the universe of discourse, in which ideas are being discussed and orthodoxies negotiated; and the universe of doxa, the realm of that which is not discussed. Doxa are taken for granted, they are accepted givens or "truths", which are juxtaposed to the field of opinion, the site of confrontation between competing discourses (Bourdieu 1977:168). Doxa thus have hegemonic status, they are axioms whose truth cannot be called into question (Gramsci 1998:210-71). During the interviews it appeared that critical awareness of Islam and its horizons was closing in; certain assumptions about Islam as misogynist, oppressive, backward and aggressive enjoyed such an axiomatic status.

\section{Neglecting intimates}

As mentioned earlier, the most striking response to conversion was what we have called 'benign neglect'. Besides a general lack of interest the parents in particular emphasised 'choice' and adopted a seemingly liberal attitude. Being asked what they thought of their daughter's conversion, Sana's parents agreed that "It's her choice" while Christine's parents explained: "We just want her to be happy [...] she could be whatever she wanted to be". Delving a bit deeper into the conversations many of these seemingly liberal statements change character. While most people presented themselves as accepting of pluralism, several statements hint towards an attitude which could be more accurately described as mere liberal rhetoric or bigotry (see Rabinowitz 1997). As 
Abu-Lughod (2002:789) and others have pointed out, respect requires engagement. With the lack of engagement we found, it is hardly surprising that ultimately the reception offered by friends and family make acceptance a "fact of life" (Farrar et al. 2012:1) more than acceptance by way of respect or embrace.

The reason why the statements emphasising the choice and happiness of the convert are more accurately described as superficially or merely rhetorically liberal is that oftentimes they were supplemented by utterances of dislike and outright rejection, which brought to light deeper-seated assumptions. While stressing conversion being Sana's choice, which he "accepted", statements by her father to the effect that "I am anti-religion, full stop" and the assertions that Islam was "a ridiculous religion" certainly did not allow for a neutral perception of her conversion as initially articulated. Similarly, Christine's father emphasising "I find it ridiculous! I accept it... I still think it's ridiculous" points to his rejection camouflaged as acceptance. While he clearly wants to be liberal and accepting of his daughter's choices, he does not actually welcome them. It is hard to believe that "she could be whatever she wanted to be" when really her choice was "ridiculous". Judging her new faith as "ridiculous" comes with an entire universe of assumptions, some of which have been elaborated above, which does not allow the conversion to be perceived in a benignly accepting manner. The rejectionism is emblematised in the superficial acceptance of any path and a simultaneous deep-seated rejection of Islam and some of the changes it brings to the converts' lives. While the hijab and the five daily prayers were mentioned several times as instances of annoyance, Sana's father also expressed his irritation at the adjustments being made for the provision of halal food: "Everything had to change because of it". Making clear that he would not respect these rules, he added with a mildly reproachful nod in the direction of his wife "but Marianne [his wife] won't cheat". It is in the interstices of the liberal rhetoric that the prejudiced perceptions of conversion come to light. In a way, the relativistic withdrawal from the issue ("It's her choice" but "I'm not interested") amounts to a protection of the self from meaningful engagement and the effects this could have.

While describing her path to conversion Christine explained how learning about Islam had caused her to question various aspects of British society, ranging from the treatment of women and consumerism to the complete absence of spirituality in many people's lives. This mirrors Tarlo's (2007:149) assertion that the presence of Islam in the public space (in the form of dress) provoked "new thoughts and feelings" and Köse's (1999:309) and Lee's (2010:150) conjectures that Islam is frequently used to question and protest modern trends such as 'hypersexuality' and consumerism. During the conversations it often seemed that it was precisely this kind of critical engagement that many respondents were seeking to avoid. The reason why 'refusal to engage' is actually a more accurate labelling of the seeming 'indifference', is because the numerous negative comments and assumptions discussed earlier indicate that the superficial neglect is, in fact, not so indifferent. Being bothered by the prayers, halal food or the hijab signal dislike, rather than neutral indifference. Symptomatic of the refusal to engage were the outright rejections to do so in the form of "I've never asked", "we don't talk about it" and "I'm just not interested". Neglect is not indifference; it is wilful. Wanting to know, on the other hand, is turning something into a legitimate subject, and ultimately means acknowledgement. 
A focus on the exterior aspects of Islam, such as food, with a certain sense of nostalgia for having lost these common external denominators ("Her favourite things for Christmas dinner were sausages wrapped in bacon") further served as evidence that a meaningful discussion of the inner aspects of Islam - the ones that were prioritised by the converts - was being evaded. Consequently, converts and relatives are communicating on two different levels with no shared understanding. While the level of engagement offered by friends and family was on the intellectual and exterior plane, for the converts it was the spiritual dimension of their new religion, which asked for engagement but was not being understood by the majority of their intimates, resulting in a loss of closeness. Rachel was the only respondent who reflected on her own stance towards spirituality and conceded: "If I'm really truthful I think I'm a bit dismissive... it just doesn't turn me on". Then she laughed. Turning serious again she reminisced with a saddened undertone "I wanted to dismiss it, I think... I couldn't really, deep down, accept it and I didn't want to engage with it".

What is problematic about the disengagement on the part of friends and family is that converts often feel profoundly misunderstood while relatives express their mystification. This does not seem unique to British converts as Hofmann (1997) and Anway (2008) report similar sentiments among converts in Germany and the United States. Hofmann explains that some converts had accused their intimates of not listening and not understanding. As a result, access to the converts' interior, to their inner life, is barred to those who would be expected to be part of it. Consequently, Hofmann (1997:168-83) writes, family frequently gets substituted by like-minded friends, often converts themselves. During my interviews several friends and family members unhappily commented on the converts' tendency to turn away from them in search for understanding elsewhere.

\section{Secularism \& modernity}

The perceptions of conversion as outlined so far cannot be understood in isolation of the social space that frames them. Understanding this social space, against which the Orientalist perception of the converts is constructed on the one hand and which allows intimates the refusal of engagement on the other hand, requires a look at its basic axioms. We will discuss notions of modernity and secularism, which seem to provide the basis for friends and family to form their perceptions.

Several converts reported that after their conversion they had been treated, in one way or another, as intellectually inferior, irrational or anti-modern. Ayshe (43) had encountered questions such as "what happened to your intelligence?" by several of her family members. In the context of talking about religion more generally, Dave called his friend's newfound religiosity in Islam "out-dated" and "a thing of the past". While Orientalism in its classic form as analysed by Said (1978) constructs the Orient as antithetical to Europe in terms of religion where Islam is seen as Christianity's heretical 'Other', this is no longer of primary relevance (Asad 1993; Gilliat-Ray 2010). Instead, the West is now presented as inherently modern and secular with any sign of religiosity being perceived as backward and out-dated (Mahmood 2005:113).

Modernity is presented as rational, mature and secular, opposed to which stand the religious, irrational and backward (Köse 1996:138; Zebiri 2011:187). Yet, within the general anti-religious attitude of modernity a hierarchy seems to exist, in which Islam 
occupies the lowest rank. Johns and Saeed (2002:209) testify to this notion when they write in the Australian context: "There is a pecking order in the popular assessment of religions in Australia. Buddhism is intellectually chic [...] Islam, on the other hand, is widely viewed through stereotypical lenses, and conversion to Islam (as opposed to Buddhism, for example) is regarded as an aberration". This perception came through in Rachel's explanation concerning her sister Maryam: "She went to Mecca, she went on the Hajj a few years ago and I think, because I'm not spiritual... actually, I think it's all a bit nutty". When discussing the fact that other religions also undertake pilgrimages, such as the Christian pilgrimage to Lourdes, she agreed that it was not unique to Islam but, after all, she thought that the Christian pilgrimages were "not quite as mad".

To Asad (2003:15) secularism is centrally located inside modernity. Secularisation theory predicted that with increasing modernisation, religion would lose prominence both in society at large and in the minds of individuals (Berger 1999:1-9; Köse 1999:302). Secularism featured strongly in the conversations with most of the relatives thinking of religion as a matter of personal choice that should be reserved for the private sphere. Relegated to the private, people were then welcome to believe whatever they wanted to believe: "Whatever works for you" (Dave, 33). As Fox (2004:356) has observantly pointed out: "We [the English] are not only indifferent but [...] we are politely indifferent, tolerantly indifferent, benignly indifferent [...] Other people are very welcome to worship Him [God] if they choose - it's a free country — but this is a private matter, and they should keep it to themselves". Slightly further down the line, she elaborates humorously: "Our benign indifference remains benign only so long as the religious of any persuasion, stay in their place and refrain from discomforting the non-practicing, spiritually neutral majority with embarrassing or tedious displays of religious zeal" (ibid.:357). The question arises: what does staying in one's place mean? The orthodox interpretation of secularism is premised on the private/public divide, building on the idea that religion could be practiced privately but should not have a place in public (Asad 2003:8; Modood 2007:72; Taylor 1994:62).

What our research reveals is a form of secularism that goes beyond the orthodox interpretation and busts the private/public dichotomy. Since we are already dealing with families - a realm traditionally thought of as the epitome of privacy - the question is where the public comes in. It does not. It seems that the problem at hand is not that the converts had carried their religiosity into the public, but rather, that they had revealed their personal (individual) private sphere to the private sphere of the family; it had become 'public' to the family. Noticing the five daily prayers, halal food or the hijab in the private family sphere was thought to be sufficiently overt so as not to engage with it. Besides the societal dimension of neighbours and others noticing that there was now a Muslim in the family, it was the perceived 'interference' with family privacy that felt like a non-secular affront. In effect, secularism meant that religion had become so private that it was not to leave the individual person. As a result, conversations within the family never penetrated into questions of belief. Even though the converts regarded Islam as most important, intimates showed little interest in learning about their beliefs. Several respondents actually pointed out that they never had any conversations about matters of belief with their friends and family and Judith described her family's conversations as "functional".

The resulting dilemma unfolds as follows: even though religiosity is certainly a matter of inner faith, it is also inherently social and shared. However, the closest 
environment to a very large degree declines any engagement with the converts' religiosity. As pointed out in Abu-Lughod's (2002:787) critique of cultural relativism, respect for diversity requires self-reflection and engagement. Without engagement there is no chance for understanding and respect to grow. How important understanding is in truly accepting the converts' choices is indicated by Jane in her account of how her mother's initial rejection changed: "Now, 13 years later things have changed a lot and my mother really embraces my Islam now... but that's because she understands it now. She doesn't see it as so different from Christianity now". In this case the mother could relate to her daughter through a shared understanding of spirituality even though they chose to follow different religious paths. The key to this shared understanding and the ensuing embrace and respect was only possible due to an active engagement with each other's beliefs (Hall 1990:227; Ramadan 2012:31; Taylor 1994:72). This kind of open communication about matters of faith enabled the mother to recognise elements of her own belief system, which helped to reduce distance and discover the similarities that were shared between the two different paradigms.

\section{Families unwound}

Even though most family members expressed no interest in the content of Islam or the converts' reasons for converting, the choice that these women made in converting did affect family relationships deeply. This was true both for religious and non-religious families.

Christine's parents explained that they were "shocked" when their daughter first told them about her conversion and that "it just felt wrong". Her mother in particular resented the perceived lack of trust, which had kept her daughter from telling her any earlier about it: "[She's] always told us everything and she just didn't tell us this". Despite the fact that there was such a degree of indifference towards religion in general, conversion shook up the taken-for-granted order. It almost seemed that as long as everybody tacitly agreed on a shared framework of norms and values, there needed to be no discussion about it. However, the moment there was a change in one of the family members away from the received paradigm, it felt "wrong" to the rest of the family and had a deeply upsetting impact. Consequently, acceptance did not emerge as the result of engagement with the disturbing news but was 'forced' onto those parents who did not want to lose the relationship with their daughter. In several interviews family members expressed the understanding that they would have lost their convert sister/daughter, had they not accepted it: "I didn't want to lose my daughter, so I accepted it".

This statement echoes what both Rachel and Judith said about their parents who were deeply hurt by the conversion. "It was quite painful for everyone", Rachel recalled, "I was very confused and upset ... I was cross really that she had done something so challenging to the family... Personally I felt very challenged by that and also for my parents that she challenged them so much and they rose to the occasion and supported her but I knew it was very, very hard for them". In agreement with her sister's statements, Judith recalled that her parents were "hugely, deeply hurt but also very generous". She also remembered-being on a spiritual search herself-feeling

\footnotetext{
${ }^{5}$ In a separate interview Christine confided that she had kept her conversion to herself in order "not to be swayed" by her family.
} 
quite attracted to the prospect of joining her sister in the Sufi order but did not dare to do so because her parents reminded her: "[Maryam] hurt us so much already... we couldn't bear it if you were to go".

Both sisters agreed that the parents felt abandoned and rejected when Maryam decided to leave Judaism for Islam. Maryam herself recognises in hindsight that her family must have felt somewhat rejected by her conversion, asking themselves "What's wrong with Judaism?". Therefore it is not only the converts who experience a feeling of being rejected but also their families. They experience the conversion as a de facto rejection of their value system, their lifestyle and ultimately themselves. Judith reported a real sense of loss at her sister's conversion and pointed out that her father's friends would have sat shiva ${ }^{6}$ for their daughter but that her parents refrained from doing that. The sense of a death-like loss articulated by Judith is also reported in Köse's (1996:137) study on converts where he refers to this phenomenon as "social death". Reflecting on the pain that Maryam's conversion had caused the family, Rachel tried to make sense of it in hindsight: "I suppose these feelings within a family are irrational, you know? When you say to me 'rationally, why were you so upset?'-well, it's because it's a family and these feelings are very deep, even though we are very different people with different interests". What these reflections show is that family ties are predicated on a shared understanding - even if tacit - concerning the 'universe of discourse' (Snow and Machalek 1984). Where this understanding is disrupted by one family member opting out of the paradigm, feelings of loss, anger and pain can ensue. Although intimate as family members, an element of strangeness was introduced into the relationship causing the converts to become 'intimate strangers'.

\section{Looking ahead}

When Judith was asked whether she thought of England as a Christian country, she answered, "No, it's a multicultural society, I would say". While dropping me off at the train station later, she wanted to know what I had found most striking during my research. I told her that it had been the perceived neglect on the part of friends and family. She nodded "yes, many people never think about the outsider". Looking at her thoughtful expression, I asked "do you see yourself as an outsider?" Without hesitation or bitterness but an unmistakable sternness in her voice she answered nodding: "As a Jew, you're concerned with the outsider all your life".

The apparent contradiction between Judith's perception of Britain as a multicultural society and her feeling like an outsider is symptomatic for the social space we have been describing. Yes, people coexist in England with a certain degree of tolerance but it is not truly multicultural in the sense that different backgrounds are equally appreciated. A hierarchy remains in place, rendering some people outsiders. Sen (2006:3) invoked an illustrative image to characterise the current state of British multiculturalism by asking "Does the existence of a diversity of cultures, which might pass one another like

\footnotetext{
${ }^{6}$ Sitting shiva refers to the weeklong mourning period in Judaism for first-degree relatives that have passed away. It usually begins following burial. In the context of conversion it signals that the convert has 'died' to the family.

${ }^{7}$ All interviews were conducted by D. Ramahi.
} 
ships in the night, count as a successful case of multiculturalism?". The image is clear: people coexist (in the literal sense of the word) but are disconnected from one another. In place of Fox's (2004:356) "polite indifference", we found neglect. And instead of mutual acknowledgement, families experienced feelings of loss, betrayal and pain.

The question arises what an appropriate and constructive alternative to the encountered neglect could be. From different disciplines including philosophy, literary criticism and anthropology scholars have formulated responses. Where Taylor (1994) speaks of "recognition" Bhabha (1990) and Hall (1990) have articulated theories of "cultural difference" and "hybridity" in the "third space". On the anthropological end, Asad (2003:179) has employed notions of "complex space" and "heterogeneous time" that go beyond constructions of multiple identities to actually allowing for "multiple ways of life". What all of these approaches share is their fundamental premise in the willingness to actively engage with the 'Other'.

We set out with the assumption that by converting to Islam the women we spoke with would in one way or another be 'othered' by the people who are closest to them. The fieldwork has revealed that this is true, but in a peculiar way. Most respondents made clear that their emotional and filial ties had not been adversely affected by the conversion and that the convert was still the same person to them. In that sense, intimacy prevailed. Strangeness was introduced into the relationship on the level of spirituality. Islam's visibility became a measure of distance between the converts and their intimates. Friends and family expressed having no understanding for the conversion but often felt challenged or angered by it. Our hunch is that despite much bias against Islam, the disruption of complex family dynamics brought about by conversion to Islam would be experienced in a similar way in cases of conversion to other religions.

Our findings give rise to an array of unanswered questions, which extend well beyond the scope of our research but which give direction to important future investigations. At the core lies the question of why it is that relatives in particular chose to benignly neglect the conversion. We take a cue from Tarlo (2007:139) in speculating that the refusal stems from the fear "not so much of the encounter or interaction but of the transformation that such interaction might engender". It seemed like a form of selfprotection, shielding people from self-reflection and not calling into question their existing worldviews. As Christine had experienced the transformative power of her engagement with Islam, friends and family usually wanted to avoid precisely such critical engagement in order not to look at the self.

A further point of departure for future research is the notion of the 'intimate stranger'. While we have taken the 'intimate stranger' to characterise the relationships between converts and their intimates, a more conceptual extension of the notion is possible. The media 'artefacts' need to be analysed as both intimate and far. How is it possible that the discursive idioms about Islam still live in the space of the home despite our contact with Muslim friends and family members? It seems that these media 'artefacts' serve as vehicles that propel into the intimate sphere very distant images that come into conflict with our personal relations and dominate them. Indeed, it feels like these 'artefacts' invade the intimate space. Why do these media images seem to have a greater impact than the people we are closest to? And finally we would like to take up our observations about the fathers' struggle to accept their daughters' conversions in order to ask whether this calls for a re-assessment of patriarchy in European 
societies. Is it possible that conversion to Islam taps into deeply embedded forms of paternalism that seem to have been in retreat in other areas of social life?

If it is not possible to extend genuine recognition to the people we love, then what are the prospects of recognising and appreciating strangers? Genuine recognition comes with a risk: the risk of being transformed. The engagement between converts and their relations was incomplete in the sense that friends and family did not want to give room to the possibility that they themselves may change through it. Instead, the observed disengagement led to the entrenchment of old stereotypes, matching the 'intimate' with the 'stranger'. The 'intimate stranger' is a powerful symbol for the dichotomies that conversion collapses. It unpacks the world of liminality where binaries of 'inside' versus 'outside' and 'us' versus 'them' dissolve. Orientalism is still present but mutates into a kind of Orientalism where geographies have collapsed: "there" has become "here". The 'intimate' is by definition on the inside and the 'stranger' on the outside. Conversion disrupts the imagined intimacy of the family. Where Islam suddenly appears in the sitting room, rather than on TV, liberalism turns into bigotry. The idea of borders collapses; the idea of the concrete and the abstract subsides; frontiers or "front"-iers erode with home itself becoming the boundary and Islam no longer outside. Conversion challenges people to accept the ambiguity inherent in life itself.

Open Access This article is distributed under the terms of the Creative Commons Attribution 4.0 International License (http://creativecommons.org/licenses/by/4.0/), which permits unrestricted use, distribution, and reproduction in any medium, provided you give appropriate credit to the original author(s) and the source, provide a link to the Creative Commons license, and indicate if changes were made.

\section{References}

Abu-Lughod, L. (2002). Do Muslim women really need saving? Anthropological reflections on cultural relativism and its others. American Anthropologist, 104(3), 783-790.

Afshar, H. (2008). Can I see your hair? Choice, agency and attitudes: the dilemma of faith and feminism for Muslim women who cover. Ethnic and Racial Studies, 31(2), 411-427.

Anway, C. L. (2008). Daughters of another path: experiences of American Women choosing Islam. Yawna Publications.

Asad, T. (1993). Genealogies of religion: discipline and reasons of power in Christianity and Islam. Baltimore and London: The Johns Hopkins University Press.

Asad, T. (2003). Formations of the secular: Christianity, Islam, modernity. Stanford: Stanford University Press.

Berger, P. L. (1999). The desecularization of the World: resurgent religion and world politics. Washington D.C: Wm. B. Eerdmans Publishing.

Bhabha, H. K. (1990). "The third space"-Interview with H. Bhabha. In J. Rutherford (Ed.), Identity: community, culture, difference (pp. 207-221). London: Lawrence \& Wishart Ltd.

Bourdieu, P. (1977). Outline of a theory of practice. Cambridge: Cambridge University Press.

Brenner, S. (1996). Reconstructing self and society : Javanese Muslim women and "the veil". American Ethnologist, 23(4), 673-697.

Brice, K. (2010). A minority within a minority: a report on converts to Islam in the United Kingdom. Faith matters.

Bullock, K. (2002). Rethinking Muslim women and the veil: challenging historical and modern stereotypes. London: International Institute of Islamic Thought.

Chua, L. (2012). Conversion, continuity, and moral dilemmas among Christian Bidayuhs in Malaysian Borneo. American Ethnologist, 39(3), 511-526.

Comaroff, J., \& Comaroff, J. (1991). Of revelation and revolution, volume 1: Christianity, colonialism, and consciousness in South Africa. Chicago \& London: University of Chicago Press. 
Esposito, J. L. (2011). Introduction. In J. L. Esposito \& I. Kalin (Eds.), Islamophobia: the challenge of pluralism in the 21st century (pp. xxi-xxxv). New York: OUP USA.

Farrar, M., Robinson, S., Valli, Y., \& Wetherly, D. P. (2012). Islam in the West: key issues in multiculturalism. London: Palgrave Macmillan.

Foucault, M. (1976). The history of sexuality: the will to knowledge: the will to knowledge v. 1.. London: Penguin.

Fox, K. (2004). Watching the English: the hidden rules of English behaviour. London: Hodder \& Stoughton.

Geertz, C. (1973). Ideology as a cultural system. In The interpretation of cultures: selected essays. New York: Basic Books.

Gilliat-Ray, S. (2010). Muslims in Britain: an introduction. Cambridge: Cambridge University Press.

Gramsci, A. (1998). Prison notebooks: selections. London: Lawrence \& Wishart Ltd.

Gullestad, M. (2006). Plausible prejudice: everyday experiences and social images of nation, culture and race. Oslo: Universitetsforlaget.

Hall, S. (1990). Cultural identity and Diaspora. In J. Rutherford (Ed.), Identity: community, culture, difference (pp. 222-240). London: Lawrence \& Wishart Ltd.

Hofmann, G. (1997). Muslimin werden: Frauen in Deutschland konvertieren zum Islam. Frankfurt: Institut fur Kulturanthropologie und Europaische Ethnologie der Universität Frankfurt.

Huntington, S. P. (1993). The clash of civilizations? Foreign Affairs, 72(3), 22-49.

Jauss, H. R. (1982). Toward an aesthetic of reception. Minneapolis: University of Minnesota Press.

Johns, A., \& Saeed, A. (2002). Muslims in Australia: the building of a community. In Y. Y. Haddad \& J. I. Smith (Eds.), Muslim minorities in the West: visible and invisible. Oxford: AltaMira Press.

Köse, A. (1994). Post-conversion experiences of native British converts to Islam. Islam and Christian-Muslim Relations, (January 2013), 37-41.

Köse, A. (1996). Conversion to Islam: a study of Native British converts. London: Kegan Paul International.

Köse, A. (1999). The journey from the secular to the sacred: experiences of Native British converts to Islam. Social Compass, 46(3), 301-312.

Köse, A., \& Loewenthal, K. M. (2000). Conversion motifs among British converts to Islam. International Journal for the Psychology of Religion, 10(2), 101-110.

Lakhdar, M., Vinsonneau, G., Apter, M., \& Mullet, E. (2007). Conversion to Islam among French adolescents and adults: a systematic inventory of motives. International Journal for the Psychology of Religion, 17(1), 1-15.

Lee, V. J. (2010). The mosque and black Islam: towards an ethnographic study of Islam in the inner city. Ethnography, 11(1), 145-163.

Lofland, J., \& Skonovd, N. (1981). Conversion motifs. Journal for the Scientific Study of Religion, 20(4), 373-385.

Mahmood, S. (2005). Politics of piety: the Islamic revival and the feminist subject. Princeton: Princeton University Press.

Matthew, S. (1984). Intimate strangers: people and divorce. Edinburgh: Mainstream Publishing.

Modood, T. (2007). Multiculturalism. Cambridge: Polity Press.

Moosavi, L. (2011). Muslim Converts and Islamophobia in Britain. The Sociology of Islam: Secularism, Economy and Politics, 247-68.

Rabinowitz, D. (1997). Overlooking Nazareth: the ethnography of exclusion in Galilee. Cambridge: Cambridge University Press.

Ramadan, T. (2012). Multiculturalism: commonality, diversity and psychological integration. In M. Farrar, S. Robinson, Y. Valli, \& D. P. Wetherly (Eds.), Islam in the West: key issues in multiculturalism. Hampshire: Palgrave Macmillan.

Rambo, L. R. (1999). Theories of conversion: understanding and interpreting religious change. Social Compass, 46(3), 259-271.

Robbins, J. (2007). Continuity thinking and the problem of Christian culture: belief, time, and the anthropology of Christianity. Current Anthropology, 48(1), 5-38.

Said, E. W. (1978). Orientalism. London: Penguin.

Said, E. W. (1985). Orientalism reconsidered. Cultural Critique, 1(Autumn), 89-107.

Said, E. W. (1997). Covering Islam: how the media and the experts determine how we see the rest of the world. London: Vintage.

Sartawi, M., \& Sammut, G. (2012). Negotiating British Muslim identity: everyday concerns of practicing Muslims in London. Culture and Psychology, 18(4), 559-576.

Scott, J. W. (2007). The politics of the veil. Princeton: Princeton University Press.

Sen, A. (2006). The uses and abuses of multiculturalism. The New Republic.

Snow, D. A., \& Machalek, R. (1984). The sociology of conversion. Annual Review of Sociology, 10, 167-190. 
Suleiman, Y. (2013). Narratives of conversion to Islam in Britain: female perspectives. Cambridge.

Tarlo, E. (2007). Hijab in London: metamorphosis, resonance and effects. Journal of Material Culture, 12(2), $131-156$.

Taylor, C. (1994). The politics of recognition. In C. Taylor (Ed.), Multiculturalism: examining the politics of recognition. Princeton University Press: Princeton.

Taylor, C. (2007). The collapse of tolerance. The Guardian. Retrieved from http://www.theguardian. com/commentisfree/2007/sep/17/thecollapseoftolerance.

van Nieuwkerk, K. (2006). Women embracing Islam: gender and conversion in the West. Austin: University of Texas Press.

van Nieuwkerk, K. (2008). Biography and choice: female converts to Islam in the Netherlands. Islam and Christian-Muslim Relations, 19(4), 431-447.

Werbner, P. (2012). Veiled interventions in pure space: honour, shame and embodied struggles among Muslims in Britain and France. In M. Farrar, S. Robinson, Y. Valli, \& D. P. Wetherly (Eds.), Islam in the West: key issues in multiculturalism. Hampshire: Palgrave Macmillan.

Wohlrab-Sahr, M. (1999). Conversion to Islam: between syncretism and symbolic battle. Social Compass, 46(3), 351-362.

Woods, O. (2012). The geographies of religious conversion. Progress in Human Geography, 36(4), 440-456.

Zebiri, K. (2008). British Muslim converts: choosing alternative lives. Oxford: Oneworld Publications.

Zebiri, K. (2011). Orientalist themes in contemporary British Islamophobia. In J. L. Esposito \& I. Kalin (Eds.), Islamophobia: the challenge of pluralism in the 21st century (pp. 173-190). New York: OUP USA. 